\title{
TU/e EmonOWEN

\section{N-Formylcarbamoylaspartame, a new aspartame-like sweetener. Synthesis and studies on stability and biological properties}

\author{
Citation for published version (APA): \\ Boesten, W. H. J., Dassen, B. H. N., Kleinjans, J. C. S., Agen, van, B., Wal, van der, S. J., Vries, de, N. K., \\ Schoemaker, H. E., \& Meijer, E. M. (1991). N-Formylcarbamoylaspartame, a new aspartame-like sweetener. \\ Synthesis and studies on stability and biological properties. Journal of Agricultural and Food Chemistry, 39(1), \\ 154-158. https://doi.org/10.1021/jf00001a030
}

DOI:

10.1021/jf00001a030

Document status and date:

Published: 01/01/1991

\section{Document Version:}

Publisher's PDF, also known as Version of Record (includes final page, issue and volume numbers)

\section{Please check the document version of this publication:}

- A submitted manuscript is the version of the article upon submission and before peer-review. There can be important differences between the submitted version and the official published version of record. People interested in the research are advised to contact the author for the final version of the publication, or visit the DOI to the publisher's website.

- The final author version and the galley proof are versions of the publication after peer review.

- The final published version features the final layout of the paper including the volume, issue and page numbers.

Link to publication

\footnotetext{
General rights

- You may freely distribute the URL identifying the publication in the public portal. follow below link for the End User Agreement:

www.tue.nl/taverne

\section{Take down policy}

If you believe that this document breaches copyright please contact us at:

openaccess@tue.nl

providing details and we will investigate your claim.
}

Copyright and moral rights for the publications made accessible in the public portal are retained by the authors and/or other copyright owners and it is a condition of accessing publications that users recognise and abide by the legal requirements associated with these rights.

- Users may download and print one copy of any publication from the public portal for the purpose of private study or research.

- You may not further distribute the material or use it for any profit-making activity or commercial gain

If the publication is distributed under the terms of Article $25 \mathrm{fa}$ of the Dutch Copyright Act, indicated by the "Taverne" license above, please 


\title{
N-Formylcarbamoylaspartame, a New Aspartame-like Sweetener. Synthesis and Studies on Stability and Biological Properties
}

\author{
Willy H. J. Boesten, ${ }^{\dagger}$ Ben H. N. Dassen, ${ }^{\dagger}$ Jos C. S. Kleinjans, ${ }^{\ddagger}$ Ben van Agen, ${ }^{\ddagger}$ Sjoerd van der Wal, ${ }^{\dagger}$ \\ N. Koen de Vries, ${ }^{\dagger}$ Hans E. Schoemaker, ${ }^{\dagger}$ and Emmo M. Meijer ${ }^{*, \dagger}$ \\ DSM Research, P.O. Box 18, 6160 MD Geleen, The Netherlands, and Department of Human Biology, State \\ University Limburg, P.O. Box 616, 6200 MD Maastricht, The Netherlands
}

\begin{abstract}
A new aspartame-like sweetener, $N$-formylcarbamoylaspartame (FC-APM), was efficiently prepared from aspartame (APM). Due to the N-protective group, FC-APM is less prone to diketopiperazine formation and therefore much more stable than aspartame at higher $\mathrm{pH}$ values $(6-9)$ and temperatures $\left(60-80^{\circ} \mathrm{C}\right)$. In vitro biotransformation experiments in tissue fractions of the rat gastrointestinal tract showed that FC-APM is less efficiently metabolized compared to APM. A relatively stable metabolite of FC-APM was isolated from tissue extracts by preparative HPLC and identified by ${ }^{13} \mathrm{C}$ NMR as the demethylated product of FC-APM. FC-APM did not show mutagenic activity in the Salmonella/ microsome assay either with or without metabolic activation. In the Sister Chromatid Exchange (SCE) test, FC-APM did increase human lymphocyte SCE frequency significantly but not dose dependently, while application of a metabolic system prevented these chromosome-damaging effects.
\end{abstract}

\section{INTRODUCTION}

Aspartame (Figure 1, structure 1) or L-aspartyl-L-phenylalanine methyl ester (APM) is a dipeptide sweetener, approximately 150-200 times as sweet as sugar. Aspartame is widely used in a variety of applications, e.g., for table-top use and in soft drinks. A drawback of aspartame, however, is its relatively low stability at higher $\mathrm{pH}$ values and at higher temperatures, thereby limiting its use.

A major degradation pathway of aspartame is the decomposition to its diketopiperazine analogue (DKP) via reaction of the amino group of the aspartic acid moiety with the methyl ester of the phenylalanine part of the molecule.

This reaction can be suppressed by protection of the amino group with an electron-withdrawing substituent. However, an unsubstituted amino group in combination with a free carboxylic acid group (zwitterionic structure of the aspartic acid moiety) has been generally considered a prerequisite for a sweet taste [cf. Kawai et al. (1980)]. Numerous derivatives of aspartame or dipeptide analogues are known that do not taste sweet. Recently, studies on sweeteners and the sweet taste perception mechanism were comprehensively reviewed by van der Wel et al. (1987).

In this paper we report on the synthesis of a new N-derivatized aspartame analogue, $N$-formylcarbamoylaspartame (FC-APM; Figure 1, structure 2), with a sweetness comparable to that of aspartame. FC-APM was discovered in the research laboratories of DSM (Boesten and Schiepers, 1980).

Some preliminary data regarding stability and metabolic and genotoxic characteristics are presented.

\section{MATERIALS AND METHODS}

Synthesis of $N$-Carbamoyl-L- $\alpha$-aspartyl-L-phenylalanine Methyl Ester. L- $\alpha$-Aspartyl-L-phenylalanine methyl ester (APM; Figure 1, structure 1) $[8.5 \mathrm{~g}(0.029 \mathrm{~mol})]$ was dissolved in a solution of $4.6 \mathrm{~g}(0.058 \mathrm{~mol})$ of potassium cyanate in $100 \mathrm{~mL}$ of water and subsequently stirred at room temperature for $24 \mathrm{~h}$. After that time, the turbid suspension obtained was filtered and the filtrate

† DSM Research.

$\ddagger$ State University Limburg.

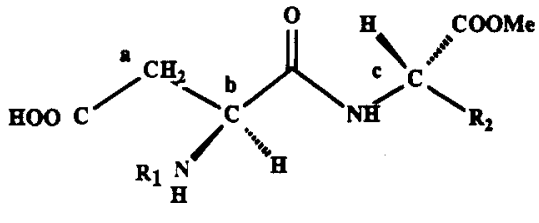

$1, \mathbf{R}_{1}=\mathbf{H}, \mathbf{R}_{2}=\mathbf{C H}_{2} \mathrm{Ph} ;$ Aspartame

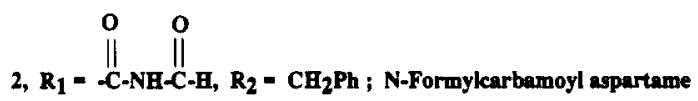

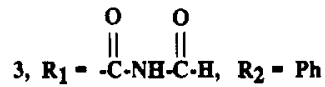

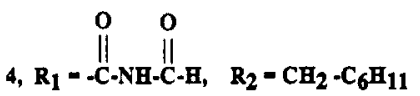

Figure 1. Dipeptide sweeteners with a $N$-formylcarbamoyl substituent.

thus obtained was acidified with $\mathrm{HCl}$ to a $\mathrm{pH}$ of 2 and subsequently evaporated at $30^{\circ} \mathrm{C}$ and $12 \mathrm{mbar}$. The deposit thereby obtained was incorporated into $250 \mathrm{~mL}$ of 2-propanol and evaporated again to dryness. This was repeated, and the crystal mass thus obtained was then incorporated in $500 \mathrm{~mL}$ of 2-propanol and subsequently stirred for $1 \mathrm{~h}$.

This suspension was then filtered for the purpose of removing the $\mathrm{KCl}$, and the filtrate obtained was evaporated and dried. $N$-Carbamoyl-L- $\alpha$-aspartyl-z-phenylalanine methyl ester (CAPM) was obtained in $85 \%$ yield $(8.3 \mathrm{~g}, 0.025 \mathrm{~mol}):{ }^{13} \mathrm{C}$ NMR $\left(\mathrm{D}_{2} \mathrm{O} / \mathrm{DMSO}-d_{6}, 4: 1\right) \delta 37.82$ (C-a; Figure 1), 38.25 (C-d; Figure 1), 52.03 (C-b; Figure 1), $54.60\left(\mathrm{OCH}_{3}\right), 55.70$ (C-c; Figure 1), $128.8(\mathrm{Ph}), 130.4(\mathrm{Ph}), 130.9(\mathrm{Ph}), 138.8(\mathrm{Ph}), 161.7(\mathrm{C}=0)$. ${ }^{1} \mathrm{H}$ NMR (DMSO- $d_{6}$ ) data have been reported by Boesten and Schiepers (1980).

Synthesis of $\boldsymbol{N}$-Formylcarbamoyl-L- $\alpha$-aspartyl-L-phenylalanine Methyl Ester. A quantity of $4 \mathrm{~g}(0.012 \mathrm{~mol})$ of $N$-carbamoyl-L- $\alpha$-aspartyl-L-phenylalanine methyl ester (C-APM) was dissolved, while being stirred at $25^{\circ} \mathrm{C}$, in a mixture of $20 \mathrm{~mL}$ of acetic anhydride and $100 \mathrm{~mL}$ of formic acid. At this temperature, a reaction was effected for $18 \mathrm{~h}$, after which time, $3 \mathrm{~mL}$ of water was added and the material subsequently evaporated to dryness.

The dry product was next incorporated in $100 \mathrm{~mL}$ of diethyl ether and subsequently filtered. The solid product obtained was washed twice on the filter with $50 \mathrm{~mL}$ of diethyl ether and subsequently dried. $N$-Formylcarbamoyl-L- $\alpha$-aspartyl-L-phenyl- 
Table 1. HPLC Phase Systems

\begin{tabular}{|c|c|c|c|c|}
\hline system & column & mobile phase & $\begin{array}{l}\text { flow rate, } \\
\mathrm{mL} / \mathrm{min}\end{array}$ & temp, ${ }^{\circ} \mathrm{C}$ \\
\hline I & $\begin{array}{l}250 \times 20 \mathrm{~mm} \text { RSil C18 } 10 \mu \mathrm{m}^{a} \\
250 \times 4 \mathrm{~mm} \text { Nucleosil } 120-3 \mathrm{C} 18^{b}\end{array}$ & $\begin{array}{l}80 \% 0.01 \mathrm{M} \mathrm{KH}_{2} \mathrm{PO}_{4} \text { (with } \mathrm{H}_{3} \mathrm{PO}_{4} \text { to } \mathrm{pH} 2.6 \text { ), } 20 \% \text { acetonitrile } \\
\mathrm{A}: \text { as system III } \\
\text { B: acetonitrile gradient, } 0 \rightarrow 15 \% \mathrm{~B} \text { in } \mathrm{A} \text { in } 15 \mathrm{~min}\end{array}$ & $\begin{array}{c}10 \\
1.5\end{array}$ & $\begin{array}{l}22 \\
40\end{array}$ \\
\hline III & $250 \times 4 \mathrm{~mm}$ Nucleosil $120-5 \mathrm{C}^{\circ} 8^{b}$ & $90 \% 50 \mathrm{mM} \mathrm{KH}_{2} \mathrm{PO}_{4}+10 \mathrm{mM} \mathrm{H}_{3} \mathrm{PO}_{4}, 10 \%$ acetonitrile & 3.0 & 40 \\
\hline
\end{tabular}

a RSL, Eke (Belgium). ${ }^{b}$ Macherey-Nagel, Düren (GFR).

-alanine methyl ester (FC-APM; Figure 1; structure 2) was obtained in $80 \%$ yield $(3.5 \mathrm{~g}, 0.0096 \mathrm{~mol}):{ }^{13} \mathrm{C}$ NMR (DMSO- $d_{6}$ ) $\delta 36.9$ (C-a; Figure 1), 37.0 (C-d; Figure 1), $49.8\left(\mathrm{OCH}_{3}\right), 52.3$ (C-b; Figure 1), 54.2 (C-c; Figure 1), 127.0 (Ph), $128.7(\mathrm{Ph}), 129.5(\mathrm{Ph})$, $137.6(\mathrm{Ph}), 153.0(\mathrm{C}=0), 163.3(\mathrm{C}=0), 170.7(\mathrm{C}=0), 172.0(\mathrm{C}=$ $0)$. ' $\mathrm{H}$ NMR (DMSO- $d_{6}$ ) data have been reported by Boesten and Schiepers (1980).

Sweetness Intensity Determinations. APM, C-APM, FCAPM, and other analogues (Figure 1, structures 3 and 4) were taste tested by three volunteers from our laboratories. The panel was able to achieve reproducible taste intensities involving sucrose solutions and these compounds.

Sweetness intensities were determined by a ranking test, with aqueous sucrose solutions of $0.5,2.0,4.0$, and $8.0 \%(w / v)$ as references. At least three double-blind tests were performed by the panel on each compound.

Genotoxicity Tests. A Salmonella/mammalian microsome mutagenicity test according to the method of Maron and Ames (1983) was performed in triplicate.

A concentration range of $0.5-10000 \mu \mathrm{g}$ of FC-APM/plate was applied by using the tester strains TA-97, TA-98, TA-100, and TA-102 with or without metabolic activation.

Effects of FC-APM on SCE frequency of human peripheral lymphocytes were analyzed according to the protocol of Dean and Danford (1984). In short, $0.4 \mathrm{~mL}$ of whole blood of a 34year-old nonsmoking male was incubated for $72 \mathrm{~h}$ at $37^{\circ} \mathrm{C}$ with $5 \mathrm{~mL}$ of RMPI 1640 medium enriched with $10 \%$ fetal calf serum in the presence of 125 units $/ \mathrm{mL}$ penicillin, $125 \mu \mathrm{g} / \mathrm{mL}$ streptomycin, $5 \mathrm{mM}$ L-glutamine, and 50 units $/ \mathrm{mL}$ heparine. Cell division was stimulated by phytohaemagglutinin (PHA). Twentyfour hours after PHA initiation, 5-bromodeoxyuridine (BrdU) was added to the lymphocytes in a final concentration of approximately $50 \mathrm{mM}$. Forty-eight hours after PHA administration, FC-APM was added of $0.2,2.0$, and $20.0 \mathrm{mM}$ concentrations, which presents the maximally soluble concentration. To study effects of metabolic activation, seperate lymphocyte cultures were centrifuged at $1100 \mathrm{rpm}$ and the lymphocytes were resuspended in liver homogenate (protein concentration $5 \mathrm{mg}$ / $\mathrm{mL}$ ).

After incubation for $1 \mathrm{~h}$ at $37^{\circ} \mathrm{C}$, the cell suspensions were centrifuged, rinsed, and resuspended in culture medium. Seventytwo hours after PHA initiation, vinblastin $(30 \mathrm{ng} / \mathrm{mL})$ or colcemid $(180 \mathrm{ng} / \mathrm{mL}$ ) was added to the lymphocyte cultures; after $2 \mathrm{~h}$, metaphases were harvested and microscopic slides prepared. After the preparations were aged, SCE's were visualized by means of the 33258 Hoechst-plus-Giemsa staining technique. Per cell culture at least 20 metaphases were evaluated, with a minimum of 40 chromosomes per cell.

All doses were tested in duplicate, negative controls and positive mytomycin C ( $100 \mathrm{ng} / \mathrm{mL})$ controls included. Statistical analysis was performed by means of the Student $t$-test for unpaired values.

Preparation of Organ Samples and Incubation Assays [cf. Burke and Orrenius (1979)]. Five male Wistar rats, in weight ranging from 200 to $250 \mathrm{~g}$, were killed under ether anesthesia by venal exsanguination. Organs of the gastrointestinal tract, e.g., stomach, ileum, colon, and liver, were removed, cleaned, and stored in buffer (Tris/KCl, $50: 150 \mathrm{mM}, \mathrm{pH} 7.4$ ). The organ/buffer ratio was 1:3 (w/v). Tissue homogenates (S9 $\mathrm{mix}$ ) and microsomal fractions were prepared according to routine procedures (Burke and Orrenius, 1979) after the respective organs were pooled. Homogenates contain cytosol and membrane-bound enzyme systems, whereas microsomes mainly contain mixedfunction oxidases. Analysis of protein content was performed
Table II. Relative Sweetness of Aspartame Analogues

\begin{tabular}{lc}
\hline compd & $\begin{array}{c}\text { rel sweetness on mole base } \\
\text { (sucrose = 1) }\end{array}$ \\
\hline APM & 200 \\
C-APM & 0 \\
FC-APM & 200 \\
structure 3 (Figure 1) & 150 \\
structure 4 (Figure 1) & 100
\end{tabular}

according to the method of Lowry et al. (1951). Tissue fractions of stomach, ileum, colon, and liver were stored at $-80^{\circ} \mathrm{C}$ until incubation.

Prior to incubation with FC-APM or APM, microsomal suspensions were diluted with buffer to protein concentrations of $1 \mathrm{mg} / \mathrm{mL}$. Homogenates were diluted conformably to the protein content ratio between organ homogenates and microsomes, resulting in protein end concentrations of $4-8 \mathrm{mg}$ / $\mathrm{mL}$. To stimulate microsome metabolic activity, a NADPH generating system consisting of $4 \mathrm{mM}$ NADP, $4 \mathrm{mM}$ glucose 6-phosphate, and 1 unit/mL glucose-6-phosphate dehydrogenase was added. FC-APM ( $1 \mathrm{mM})$ or APM $(1 \mathrm{mM})$ was incubated with respectively tissue homogenate or microsomal fraction in buffer (final volume $2 \mathrm{~mL}$ ) at $37^{\circ} \mathrm{C}$ during $1 \mathrm{~h}$. All incubations were performed in triplicate. Subsequently, samples were centrifugated at $3000 \mathrm{rpm}$, supernatants being filtered through a $0.22-\mu \mathrm{m}$ Millipore filter and stored on ice for immediate HPLC analysis.

HPLC. High-performance liquid chromatographic analysis of FC-APM and APM in homogenate or microsome supernatant was adapted from the method of Verzella and Mangia (1985).

A Kratos Analytical HPLC apparatus equipped with a 783 variable UV detector set at $\lambda=212 \mathrm{~nm}$ and $\mathrm{AU}=0.2$ was employed. The stationary phase consisted of a $150 \times 4.6 \mathrm{~mm} 5$ RP 18 column in combination with an appropriate guard column (Chrompack, Middelburg, The Netherlands). The mobile phase contained $0.1 \mathrm{M} \mathrm{KH}_{2} \mathrm{PO}_{4}(\mathrm{pH} 2.5)$ and acetonitrile $(80: 20 \mathrm{v} / \mathrm{v})$ and was recycled at a flow rate of $2 \mathrm{~mL} / \mathrm{min}$. Filtered supernatants of tissue homogenate or microsome fractions were directly analyzed (injection volume of $20 \mu \mathrm{L}$ ). No internal standard was applied. Calibration concentrations of FC-APM and APM were dissolved in liver microsome supernatant. For preparative chromatography of metabolites a single incubation, in the presence of microsomal fractions, of $10 \mathrm{~mL}$ of FC-APM at a concentration of $11.5 \mathrm{mM}$ was made (see Metabolic Studies) Prior to HPLC, the incubate was filtered through a Bakerbond C8 SPE column and eluted with $4 \mathrm{~mL}$ of eluent. Nine times 1.5 $\mathrm{mL}$ of sample was injected, and the collected eluates were combined, adjusted to $\mathrm{pH} 5$, and evaporated at reduced pressure at $60^{\circ} \mathrm{C}$ to a moist residue. A Varian $5000 \mathrm{HPLC}$ (Varian, Walnut Creek, CA) equipped with a Waters 481 variable-wavelength detector (Waters, Milford, MA) was used for preparative purpose (system I); an HP 1090 M DR5 system with built-in diode array detector was used as an analytical liquid chromatograph (HewlettPackard, Waldbronn, GFR) to check the purity and the identity of the isolated fractions.

Chromatograms were recorded at $200 \mathrm{~nm}$. Three phase systems were utilized (see Table I). Separation times for the analytes studied in systems II and III are equivalent, but only the isocratic system III allows the application of the Martin rule (Karger et al., 1973), while the overall resolution in system II is larger (see Figure 3). According to the Martin rule the logarithm of the capacity factor of an analyte is the summation of the logarithms of the capacity factor contributions of its constituent groups.

All chemicals used were of HPLC grade.

Determination of Amino Acids. Concentrations of amino acids, e.g., phenylalanine, tyrosine, aspartame, and glutamate, 
Table III. Percentage Decrease of $1 \mathrm{mM}$ Incubating Concentrations of FC-APM and APM (Mean \pm SD, in Triplicate Incubation) after $1 \mathrm{~h}$ in Vitro Metabolism in Tissue Homogenates or Microsomes of Rat Gastrointestinal Tract

\begin{tabular}{|c|c|c|c|c|}
\hline \multirow[b]{2}{*}{ organ } & \multicolumn{2}{|c|}{$\%$ metabolized APM } & \multicolumn{2}{|c|}{$\%$ metabolized FC-APM } \\
\hline & homogenate & microsomes & homogenate & microsomes \\
\hline $\begin{array}{l}\text { liver } \\
\text { stomach } \\
\text { ileum } \\
\text { colon }\end{array}$ & $\begin{array}{l}100.0 \pm 0.0 \\
100.0 \pm 0.0 \\
100.0 \pm 0.0 \\
100.0 \pm 0.0\end{array}$ & $\begin{aligned} 20.8 & \pm 3.1 \\
0.0 & \pm 2.5 \\
71.8 & \pm 1.3 \\
0.0 & \pm 1.7\end{aligned}$ & $\begin{array}{r}42.2 \geq 3.7 \\
10.2 \pm 1.3 \\
100.0 \pm 0.0 \\
57.7 \pm 1.1\end{array}$ & $\begin{array}{r}11.2 \geq 0.9 \\
3.8 \pm 4.0 \\
74.4 \pm 9.4 \\
0.3 \pm 1.5\end{array}$ \\
\hline
\end{tabular}

Table IV. Amino Acid Concentrations after Incubation of $1 \mathrm{mM}$ APM or FC-APM

\begin{tabular}{|c|c|c|c|c|c|}
\hline \multirow[b]{2}{*}{ organ } & & \multicolumn{4}{|c|}{ amino acid level, $\mu \mathrm{M}$} \\
\hline & & Asp & Glu & Phe & $\mathrm{Ty}$ \\
\hline liver & $\begin{array}{l}\quad \text { A. In } \\
\text { control } \\
\text { APM } \\
\text { FC-APM }\end{array}$ & $\begin{array}{r}\text { sue } \mathrm{Hc} \\
38 \\
619 \\
34\end{array}$ & $\begin{array}{c}\text { genate } \\
78 \\
76 \\
67\end{array}$ & $\begin{array}{r}13 \\
780 \\
33\end{array}$ & $\begin{array}{l}12 \\
10\end{array}$ \\
\hline stomach & $\begin{array}{l}\text { control } \\
\text { APM } \\
\text { FC-APM }\end{array}$ & $\begin{array}{r}32 \\
780 \\
34\end{array}$ & $\begin{array}{l}67 \\
69 \\
55\end{array}$ & $\begin{array}{r}12 \\
838 \\
36\end{array}$ & \\
\hline ileum & $\begin{array}{l}\text { control } \\
\text { APM } \\
\text { FC-APM }\end{array}$ & $\begin{array}{r}830 \\
1330 \\
850\end{array}$ & $\begin{array}{l}1500 \\
1440 \\
1400\end{array}$ & $\begin{array}{r}604 \\
1290 \\
980\end{array}$ & $\begin{array}{l}538 \\
545 \\
480\end{array}$ \\
\hline colon & $\begin{array}{l}\text { control } \\
\text { APM } \\
\text { FC-APM }\end{array}$ & $\begin{array}{r}38 \\
721 \\
38\end{array}$ & $\begin{array}{l}69 \\
72 \\
68\end{array}$ & $\begin{array}{r}26 \\
856 \\
39\end{array}$ & $\begin{array}{l}23 \\
32 \\
25\end{array}$ \\
\hline liver & $\begin{array}{l}\quad \text { B. In } \\
\text { control } \\
\text { APM } \\
\text { FC-APM }\end{array}$ & $\begin{array}{r}\text { rosom } \\
10 \\
158 \\
8\end{array}$ & $\begin{array}{c}\text { raction } \\
9 \\
9 \\
\text { nd } \\
\text { a }\end{array}$ & $\begin{array}{r}4 \\
155 \\
7\end{array}$ & \\
\hline stomach & $\begin{array}{l}\text { control } \\
\text { APM } \\
\text { FC-APM }\end{array}$ & $\begin{array}{r}5 \\
48 \\
13\end{array}$ & $\begin{array}{l}4 \\
5 \\
6\end{array}$ & $\begin{array}{r}2 \\
15 \\
5\end{array}$ & \\
\hline ileum & $\begin{array}{l}\text { control } \\
\text { APM } \\
\text { FC-APM }\end{array}$ & $\begin{array}{r}\text { nd } \\
354 \\
47\end{array}$ & $\begin{array}{l}\text { nd } \\
60 \\
58\end{array}$ & $\begin{array}{r}\text { nd } \\
479 \\
52\end{array}$ & $\begin{array}{l}\text { nd } \\
41 \\
31\end{array}$ \\
\hline colon & $\begin{array}{l}\text { control } \\
\text { APM } \\
\text { FC-APM }\end{array}$ & $\begin{array}{r}5 \\
19 \\
5\end{array}$ & $\begin{array}{l}3 \\
3 \\
3\end{array}$ & $\begin{array}{r}\text { nd } \\
5 \\
2\end{array}$ & \\
\hline
\end{tabular}

a nd, nondetectable.

in filtered supernatants of incubate mixtures were analyzed after deproteinization with sulfosalicylic acid $(5 \% \mathrm{w} / \mathrm{v})$ on a LKB 4400 amino acid analyzer running a physiological program with $5 \mathrm{Li}^{+}$buffer system according to the method of van Eijck et al. (1988).

NMR. High-resolution ${ }^{13} \mathrm{C}$ NMR spectra were obtained with composite pulse decoupling on a Bruker AM-400 at $100.61 \mathrm{MHz}$. Samples were measured in DMSO- $d_{6 .}$. Chemical shifts are reported relative to the DMSO signal at $\delta 39.7$. Spectra were recorded with $64 \mathrm{~K}$ data points, and approximately 12000 scans were collected with a relaxation delay of $3 \mathrm{~s}$. Before Fourier transformation, exponential multiplication was used (line broadening of $2 \mathrm{~Hz}$ ).

\section{RESULTS}

Sweetness and Stability of $\boldsymbol{N}$-Formylcarbamoylaspartame. Surprisingly, it was found that FC-APM (Figure 1 , structure 2), lacking the zwitterionic structure thought to interact with the taste receptor, still elicits a sweet taste qualitatively and quantitatively comparable with that of aspartame (Table II). Moreover, derivatization of analogous dipeptide sweeteners (Figure 1, structures 3 and 4) with a $N$-formylcarbamoyl substituent also resulted in the formation of products with a sweet taste. In contrast, both the corresponding carbamoyl and the corresponding formyl derivatives do not taste sweet.
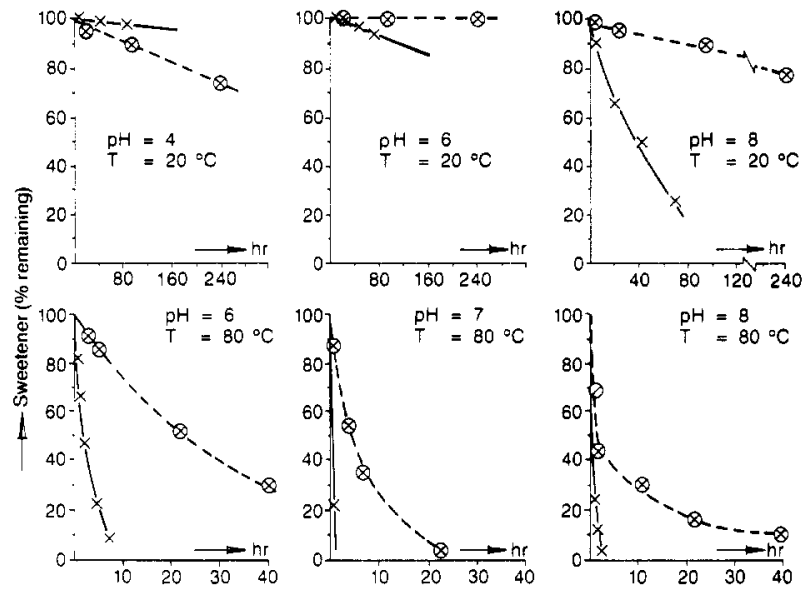

Figure 2. Stability of FC-APM ( . . -) compared to APM $(-)$ at different $\mathrm{pH}$ values and temperatures. The decrease in sweetener concentration in aqueous buffer systems (Titrisol, Merck) was measured by HPLC (see Materials and Methods).

Table V. Capacity Factor Contributions $\left(\log k_{1}\right)$ Due to Several Groups if

\begin{tabular}{lcccccc}
\hline \multicolumn{1}{c}{ compd } & $\begin{array}{c}\text { log } \\
k^{\prime}{ }^{2}\end{array}$ & AP & methyl & $\begin{array}{c}\text { carba- } \\
\text { moyl }\end{array}$ & formyl & $\begin{array}{c}\text { formyl- } \\
\text { carbamoyl }\end{array}$ \\
\hline AP & 0.20 & 0.20 & & & & \\
APM & 0.78 & 0.20 & 0.58 & & & \\
C-APM & 1.05 & 0.20 & 0.58 & 0.27 & & \\
F-APM & 1.15 & 0.20 & 0.58 & & 0.37 & \\
FC-APM & 1.31 & 0.20 & 0.58 & & & 0.53 \\
C-APM metab & 0.47 & 0.20 & & 0.27 & & \\
F-APM metab & 0.57 & 0.20 & & & 0.37 & \\
FC-APM metab & 0.72 & 0.20 & & & & 0.52
\end{tabular}

${ }^{a} \log k^{\prime}=\sum_{i} \log k_{i} ; i$ denotes the constituent group of the analyte.

Due to the electron-withdrawing substituent, it can be expected that formylcarbamoylaspartame is less prone to DKP formation and thus will be more stable than aspartame, especially at higher $\mathrm{pH}$ values and at higher temperatures. Results of some of the stability studies are graphically represented in Figure 2, from which data it can be concluded that FC-APM is indeed dramatically more stable at room temperature and $80^{\circ} \mathrm{C}$ than aspartame at least at neutral and more basic $\mathrm{pH}$ values. The difference in stability decreases when the $\mathrm{pH}$ is lowered, partly because at lower $\mathrm{pH}$ values aspartame is less prone to DKP formation and partly because hydrolysis of the formyl group of FC-APM occurs, resulting in the corresponding nonsweet carbamoyl derivative. Another aspartame decomposition pathway at lower $\mathrm{pH}$ values is ester hydrolysis, yielding the corresponding nonsweet dipeptide dicarboxylic acid. A similar decomposition reaction also occurs with FC-APM.

Metabolic Studies. Results of in vitro biotransformation of FC-APM and APM in tissue fractions of rat gastrointestinal tract are presented in Table III. It is clearly indicated that APM is completely metabolized by fractionized organs of the gastrointestinal tract as judged from the disappearance of APM from the reaction mixture; FC-APM, however, is only metabolized completely by ileum homogenate, whereas homogenates of other organs are less effective.

Microsomal fractions are not or less capable of in vitro degradation of APM and FC-APM. It is furthermore shown that in vitro metabolism of APM and FC-APM varies with the site of origin of the metabolizing organ fractions, homogenates as well as microsomal fractions of the small intestine being most active.

Table IV shows results of amino acid analysis of incubated mixtures. 
Table VI. ${ }^{13} \mathrm{C}$ NMR Data of FC-APM and Metabolite in DMSO- $\tilde{d}_{6}$ (ppm)

\begin{tabular}{ccccccc}
\hline compd & C-a & C-b & C-c & C-d & OMe & C=0 \\
\hline FC-APM & 36.9 & 52.3 & 54.2 & 37.0 & 49.8 & $153.0,163.3,170.7,172.0,172.0$ \\
metab & 37.9 & 51.4 & 56.0 & $b$ & - & $153.8,163.8,170.9,173.9,174.6$
\end{tabular}

a See for numbering Figure $1 .{ }^{b}$ Obscured by the DMSO- $d_{6}$ signal.

Table VII. Effects of FC-APM on Human Lymphocyte SCE Frequency

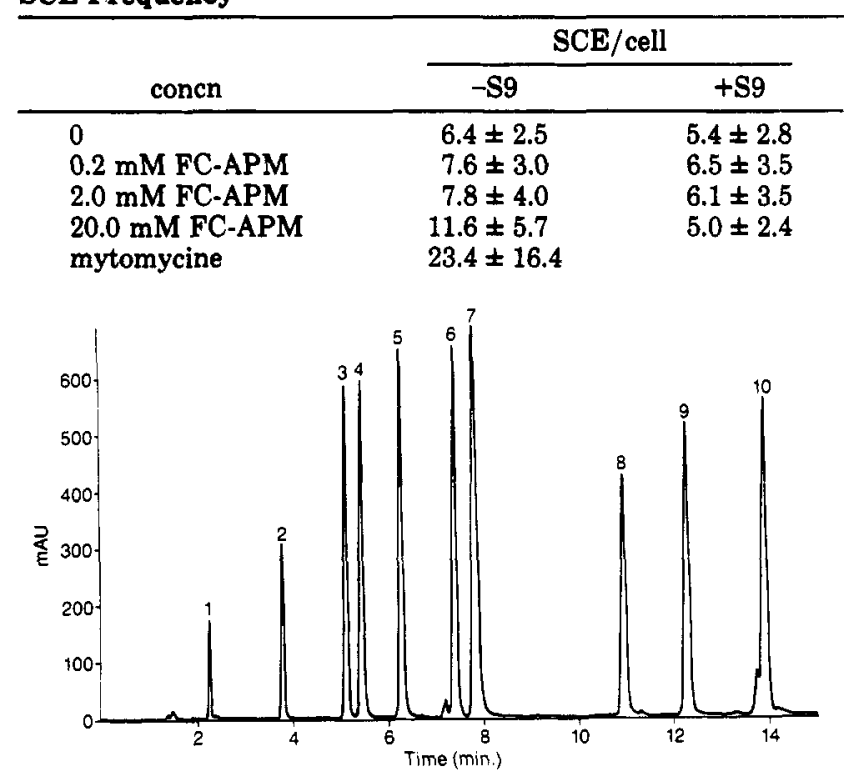

Figure 3. Separation of FC-APM and probable metabolites, HPLC system II (see Materials and Methods). Analytes: 1, PA (phenylalanyl aspartate); 2, AP (aspartylphenylalanine); $3, \mathrm{DKP}$; 4, C-APM metabolite; 5, F-APM metabolite; 6, FC-APM metabolite; 7, APM; 8, C-APM; 9, F-APM; 10, FC-APM.

In vitro biotransformation of APM correlates with increases of phenylalanine and aspartate levels while concentrations of tyrosine and glutamate remain unaffected. Metabolism of FC-APM does not influence the amino acid content of homogenates or microsomes.

In vitro degradation of FC-APM goes along with the occurrence of an unknown peak in the HPLC chromatogram, approximately at the APM spot. Peak heights of this unknown substance correlate well $(r=0.996, p<0.05)$ with the decrease in FC-APM concentrations on a percentage base.

The unknown FC-APM metabolite (peak 6 in Figure 3) was isolated by preparative HPLC. The metabolites of C-APM, F-APM, and FC-APM were identified from their capacity factors on the basis of the Martin rule (see Table V) as the demethylated products; of course, the contribution to the overall retentive interaction of formyl and carbamoyl groups in the formylcarbamoyl group of FCAPM is not stochastic. As a control experiment C-APM was subjected to demethylation in $\mathrm{NaOH}$. The product is chromatographically identical with the liver metabolite.

${ }^{13} \mathrm{C} \mathrm{NMR}$ measurements were done to confirm the identification of the preparative HPLC fraction of the FC-APM metabolite. For comparison, FC-APM was also measured under identical conditions. Results are given in Table VI.

It is clear that the metabolite lacks a methyl ester group. It is further evident that the metabolite still has five carbonyl groups. Especially the carbonyl resonance at $\delta 153.8$ is very characteristic (Bremser et al., 1982) since it belongs to a NHCONH group, which indicates that the metabolite is a formylcarbamoylaspartame derivative.

In conclusion, the ${ }^{13} \mathrm{C} N \mathrm{NMR}$ data show that the metabolite is the demethylated product of FC-APM.
Genotoxicity Testing. FC-APM did not show mutagenic activity (results not shown) within the concentration range $0.5-10000 \mu \mathrm{g}$ of FC-APM in the Salmonella $/ \mathrm{mi}$ crosome assay with or without metabolic activation (S9 mix from Aroclor induced rats). Results on SCE testing of FC-APM (Table VII) show significant increases at FCAPM concentrations of 0.2 and $20.0 \mathrm{mM}$ in the absence of $\mathrm{S} 9 \mathrm{mix}$. Linear regression analysis showed no statistically reliable concentration-effect relations, indicating no distinct effect of FC-APM on lymphocyte SCE incidence.

Application of a metabolic system prevented any effects of FC-APM on lymphocyte SCE frequency, suggesting that the demethylated metabolite of FC-APM has no genotoxic potential.

\section{DISCUSSION}

The discovery of FC-APM (Figure 1, structure 2; Boesten and Schiepers, 1980) was again an example of serendipity. In the search for a new route to APM, the sweet taste of an unknown intermediate was observed. Spectral analysis and independent synthesis established its structure as $N$-formylcarbamoylaspartame. Subsequent research showed that other dipeptide sweeteners (Figure 1, structures 3 and 4) with the $N$-formylcarbamoyl substituent also elicit a sweet taste. However, the corresponding $N$-carbamoyl dipeptides, intermediates in the synthesis of the $N$-formylcarbamoyl dipeptides, do not taste sweet. Before 1980 , the only N-protected aspartame-derivative reported to have a sweet taste was $N$-trifluoroacetylaspartame (Lapidus and Sweeney, 1973). Tinti et al. (1981) showed that most probably the receptor sites for the $\mathrm{NHCOCF}_{3}$ group and the $\alpha-\mathrm{NH}_{3}{ }^{+}$group of the dipeptide ester are different. Tinti and Nofre (1984) described the most potent class of $\mathrm{N}$-protected dipeptide sweeteners discovered up to now, which are parasubstituted arylureas having sweetness potencies $10000-$ 14000 times that of sucrose.

All these results are seriously challenging the concept that the zwitterionic structure of the aspartic acid moiety is a prerequisite for a sweet taste [cf. Kawai et al. (1980)].

The easy preparation from APM and the pronounced stability compared to APM in weakly neutral and alkaline environments ( $\mathrm{pH}$ 6-9) at room temperature and higher temperatures $\left(80^{\circ} \mathrm{C}\right)$, make FC-APM a potential candidate for special applications, e.g., bakery.

Our results from the in vitro studies on the metabolic fate of FC-APM in rat tissue fractions demonstrate that the metabolic clearance of FC-APM occurs at a slower rate than of $A P M$, which is metabolized quickly and completely by gastrointestinal tissue homogenates.

Cytosolic metabolism of FC-APM is only to a small extent paralleled by increases of amino acids concentrations, in contrast with APM. It is to be expected that oral intake of FC-APM by intact organisms will not cause increases in plasma amino acids levels which are characteristic for APM effects. Hypothesized hydrolysated metabolic intermediates of FC-APM, e.g., carbamoylAPM, formyl-APM, or APM, have not been identified. In contrast, a biologically rather stable metabolite has been found in vitro and characterized as the demethylated formylcarbamoylaspartate phenylalanine ester. The bio- 
logical fate of this compound is not known. Further research should focus on kinetics and metabolism of this metabolite in relation with the parent compound FC-APM, to be studied in intact organisms.

The results on the in vitro genotoxicological properties of FC-APM indicate that FC-APM is not mutagenic to Salmonella typhimurium tester strains and has limited capacity to induce chromosome damage in human lymphocytes. Since in vitro metabolism of FC-APM reduces this effect on SCE frequency completely, it is concluded that this slight genotoxic effect of FC-APM probably will not be expressed in vivo.

To complete the genotoxicological studies on FC-APM, possible induction of structural DNA damage, e.g., point mutations, should be evaluated in an in vitro mammalian (preferably human) cell system.

\section{ACKNOWLEDGMENT}

H. A. J. Linssen, T. A. Verstappen, and T. G. J. M. van Dooren are gratefully acknowledged for their technical assistance.

\section{LITERATURE CITED}

Boesten, W. H. J.; Schiepers, L. A. C. Dipeptide Sweetener. U.S. Patent 4, 371, 464; Sept 4, 1980; Chem. Abstr. 097-092768 K.

Bremser, W.; Franke, B.; Wagner, H. In Chemical Shift Ranges in Carbon-13 NMR Spectroscopy; Verlag Chemie: Weinheim, 1982; p 171.

Burke, M. D.; Orrenius, S. Isolation and comparison of endoplasmatic reticulum membranes and their mixed function oxidase activities from mammalian extrahepatic tissues. Pharmacol. Ther. 1979, 7, 549-599.

Dean, B. J.; Danford, N. Chemically induced chromosome damage. In Mutagenicity testing, a practical approach; Venitt, S., Parry, J. M., Eds.; IRL Press: Oxford, 1984; pp 187-232.
Karger, B. L.; Snijder, L. R.; Horrath, Cs. In An Introduction to Separation Science; Wiley: New York, 1973; pp 55-57.

Kawai, M.; Chorev, M.; Marin-Rose, J.; Goodman, M. Peptide Sweeteners: 4-Hydroxy and methoxy substitution of the aromatic ring in L-aspartyl-L-phenylalanine methyl ester. Structure-taste relationships. J. Med. Chem. 1980, 23, 420424.

Lapidus, M.; Sweeney, M. L-4'-Cyano-3-(2,2,2-trifluoroacetamido) succinanilic acid and related synthetic sweetening agents. J. Med. Chem. 1973, 16, 163-166.

Lowry, O. H.; Rosebrough, N. J.; Farr, A. L.; Randall, R. J. Protein Measurement with the Folin Phenol Reagent. J. Biol. Chem. $1951,193,265-275$.

Maron, D. M.; Ames, B. N. Revised methods for the Salmonella mutagenicity test. Mutat. Res. 1983, 113, 173-215.

Tinti, J. M.; Nofre, C. Synthetic Sweeteners. U.S. Patent 4,645,678; Sept 17, 1982; Chem. Abstr. 101-152354 K.

Tinti, J. M.; Nofre, C.; Durozard, D. Studies on sweeteners requiring the simultaneous presence of both the nitrogen dioxide/cyanide and carboxylgroups. Naturwissenschaften $1981,68,143$.

Van der Wel, H.; van der Heijden, A.; Peer, H. G. Sweeteners. Food Rev. Int. 1987, 3 (3), 193-268.

Van Eijck, H. M. H.; van der Heijden, M. A. H.; van Berlo, C. L. H.; Soeters, P. B. Fully automated liquid chromatographic determination of amino acids. Clin. Chem. 1988, 34, 25102513.

Verzella, G.; Mangia, A. High performance liquid chromatographic analysis of aspartame. J. Chromatogr. 1985, 346, 417421

Received for review February 12, 1990. Revised manuscript received July 11, 1990. Accepted July 16, 1990.

Registry No. 1, 22839-47-0; 2, 82778-17-4; 2 (demethyl derivative), 129966-82-1; C-APM, 82778-16-3. 